\title{
Determination of Depth to Magnetic Sources Using Spectral Analysis of High Resolution Aeromagnetic Data over IBBI and Environs, Middle Benue Trough, North Central Nigeria
}

\author{
S. C. Alkali ${ }^{1}$, S. Kasidi ${ }^{2}$ \\ Department of Geology University of Maiduguri, Nigeria
}

\begin{abstract}
Two dimensional spectral analyses of high resolution aeromagnetic data using Oasis Montaj version 7.5 were carried out to determine the average depths of magnetic sources in IBI and environs North-Central Nigeria. The results suggest the existence of two source depths and a single source depth. The deeper magnetic sources vary between 1200 to $4800 \mathrm{~m}$ and the shallower magnetic sources; vary between 500 to $1000 \mathrm{~m}$. The deeper sources correspond the basement topography underlying the area, while the shallower magnetic sources are associated with basic intrusive within the Middle Benue Trough and the adjoining basement formed by the Cameroon Volcanic line. Aeas of deeper magnetic sources are potential sites for hydrocarbon exploration within the Benue rift and groundwater exploration on the basement area.
\end{abstract}

Keywords: Magnetic source, Aeromagnetic data, Basement, Intrusive, and Oasis montaj

\section{Introduction}

The release of aeromagnetic data collected over the Benue Trough by the Nigerian Geological Survey Agency (NGSA), has been an upsurge of interest in the quantitative interpretation of these data, [22] carried out an interpretation of aeromagnetic anomalies over the Lower and Middle Benue Trough using non - linear optimization techniques. The author interpreted the anomalies in terms of basic intrusive bodies which occur either within the Cretaceous sediments and/or the metamorphic basement. Detailed interpretation of aeromagnetic anomalies over the trough $[22,23,24]$ revealed that the magnetic anomalies over the Benue Trough can be accounted for in terms of the combined effects of a basement of a variable topographic relief and magnetic character and some deeply buried intrusive bodies of basic to intermediate composition. More recently,(27) work on Upper Benue Trough using Source Parameter Imagine, estimated the depth of sedimentary/basement interface between $0.96 \mathrm{~km}$ and $5.862 \mathrm{~km}$. (25), through spectral analysis of aeromagnetic data estimated the thickness of the Cretaceous sediments over the Abakaliki Anticlnorium to vary between 1.2 and $2.5 \mathrm{~km}$. The highest depth can be found at the south-central part to the northeastern part. However, relatively higher depths are scattered around the northern and southern parts.[3] estimated thickness of over $10 \mathrm{~km}$ around Maiduguri depression, but less than $5 \mathrm{~km}$ was later proved from seismic reflection data.

[16] Obtained 1.6 to $5 \mathrm{~km}$ for deeper sources around the Middle Benue, while $0.06 \mathrm{~m}-1.2 \mathrm{~km}$ was obtained for shallower magnetic sources. [13] obtained 2 to $2.62 \mathrm{~km}$ for deeper source and $0.07 \mathrm{~km}$ to $0.63 \mathrm{~km}$ for shallower ones from spectral analysis of Upper Benue Trough; (29) obtained a maximum depth of $3.39 \mathrm{~km}$ at Nupe Basin; [18] obtained depth range of 0.625 to $2.219 \mathrm{~km}$ for deeper source and an average of $0.414 \mathrm{~km}$ for shallow sources at the Upper Benue
Trough; [15] estimated a depth range of about 0.42 to $8.0 \mathrm{~km}$ around the southwest of the Chad Basin.

[1] work over the Younger Granite complex of North Central Nigeria showed that the trend of the magnetic anomaly is characterized by five main directional lineaments. The NE SW linear structures belong to fractures associated with major movement produced by previous tectonic forces. Pegmatite and quartz zones are associated with the NNE SSW linear structures and the NNW - SSE and the NW - SE structural lines were probably produced by ductile and brittle deformational events that affected the Nigerian Basement rocks.

[2]. also worked on the depth estimation of digitized aeromagnetic data of the Western Part of the Younger Granite rocks close to the study area), observed that the Younger Granites rocks of North Central Nigeria are characterized by total magnetic intensity values ranging from 32670 to $33070 \mathrm{nT}$.

The present area of study covers a land mass of $6,050 \mathrm{~km}^{2}$ and lies between latitudes $8^{\circ} 00^{\prime}$ and $10^{\circ} 00^{\prime} \mathrm{N}$ and longitudes $9^{0} 00^{\prime}$ and $10^{\circ} 00^{\prime} \mathrm{E}$ (Fig.1). The research is intended to estimate the depths to magnetic sources using spectral analysis of high resolution aeromagnetic data. 


\section{International Journal of Science and Research (IJSR) ISSN (Online): 2319-7064}

Index Copernicus Value (2013): 6.14 | Impact Factor (2015): 6.391

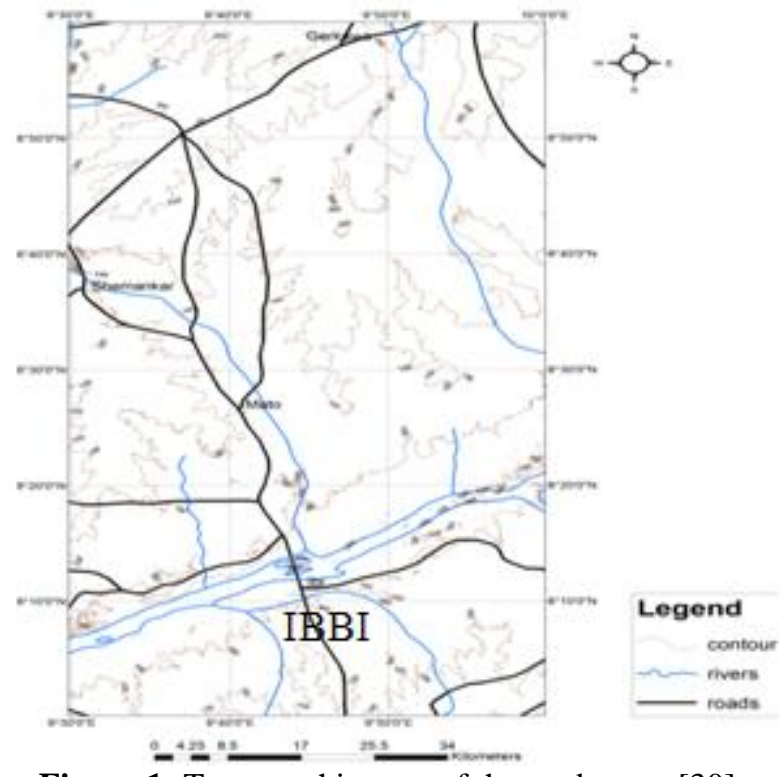

Figure 1: Topographic map of the study area [30]

\section{Geology of the Study Area}

The geology of the study area is made up of the Precambrian Basement complex rocks, which are considered to be undifferentiated basement consisting mainly migmatitesgneisses complex, Older Granite rocks, Cretaceous sedimentary rocks and Tertiary to recent volcanic rocks (Fig.2). The migmatite gneisses exhibit great variation in the percentage of light and dark mineral components that resulted from the protolith they were derived and pressure temperature condition which they formed.

The older granites of Nigeria intrude the basement complex. Older granite rocks are seen within great part of the studied area. They outcropped at the northern part

The Cretaceous sedimentary rocks, include, rocks of Dukul, Yolde and Bima Sandstone Formation in the southern part. [5] Suggested that the Cretaceous sediments belongs to the oldest sedimentary Bima Sandstone whose lower beds are more feldspathic than the higher beds. The age of the formation ranges from Upper Albian to Turonian. The Tertiary-Recent volcanic rocks, which consist of basalts, trachyte and rhyolite of Cameroon Volcanic Line outcropped at Kiri, Ruru Sama and Fillinga.

The Bima Sandstone, which overlies unconformably on the basement complex in the northwestern part at the base of sedimentary succession, was derived from granitic rocks [21]. This formation was deposited under continental condition (fluvial, deltaic, lacustrine) and is made up of coarse to medium grained sandstones, intercalated with carbonaceous clays, shales and mudstones. [5] subdivided the Bima Sandstone into a Lower, Middle and Upper Bima.

The Middle Bima is reported to be shaley in most parts with some limestone intercalations and was assumed to be deposited under a more aqueous anoxic condition. The lower beds of the formation are invariably feldspathic. According to (4), the Bima Formation in the Yola Arm, form a coarsening upward (fining upward) Sequences. The coarsening upward sequence is more common in the conglomerates on the margin of the basin and range in thickness between 20 to $30 \mathrm{~m}$. The coarsening upward sequence and fining upward sequence is interpreted as an alluvial fan system which reflect fan -lobe, caused by vertical movements of the basin floor, while the fining upward sequence are thought to be due to auto cyclic shifting.

The Bima Sandstone comprises solely clastic sediments laid down under non-marine conditions and according to [24], the sandstone varies in thickness from about 0.5 to $4.6 \mathrm{~km}$. [4] subdivided, Bima Sandstones into three members; Bima 1, Bima 2, and Bima 3, but Bima 1 member outcrops only in the core of the Lamurde Anticline south of Kaltungo inlier. According to [21] the thickness varies from 100 to $3000 \mathrm{~m}$ with its maximum development at the Lamurde Anticline, where the thickness exceeds $3000 \mathrm{~m}$. The Bima 1 member is said to consist of about $400 \mathrm{~m}$ of sandstone and argillaceous rocks. The Bima 2 is made up of $800 \mathrm{~m}$ of coarse sandstones interbeded with clays and shales, while the Bima 3 which is at the top has a thickness of about $1700 \mathrm{~m}$ and comprised essentially of coarse sandstone.

The Yolde Formation is a variable sequence of calcareous sandstone and shale, which marks the transition from continental to marine sedimentation. The base of the formation is defined by the appearance of marine shale and at the top, by the disappearance of sandstone and the commencement of limestone shale deposits. The type section occurs in Dadiya Anticline and is exposed in the stream at Yolde, where $166 \mathrm{~m}$ thick sedimentary deposits were exposed [17]. The Yolde Formation is present around the south-western part of the study area, and constitutes the transition facies between continental and marine sedimentation.

The Dukul Formation; is the limestone -shale series recognized by [6]. The type locality is at Dukul where beds of shales interbeded with thin limestone. It has a total thickness of about $100 \mathrm{~m}$. This marked the beginning of widespread of shallow marine transgression which covered most of the northeastern area by the Turanian times and coincides with the lower part of the Pindiga Formation in Gombe area.

The Tertiary- Recent volcanic rocks in the area consist of the basalts, trachyte, rhyolite, and newer basalts of eastern arm of Cameroon volcanic line. [7] discussed the events of volcanizism in the Benue Valley, and the Adamawa massif, which was compared with that of the Cameroon volcanic line. In this area the volcanic rocks are dominantly basalts.

Stratigraphically, the basement complex rocks are the oldest. The Quaternary deposit the youngest which were formed mainly from the weathered rocks dominating the northwestern part of the area. Alluvium in the area is deposited at the bank of the Benue Valley in the northwestern part. 


\section{International Journal of Science and Research (IJSR) \\ ISSN (Online): 2319-7064}

Index Copernicus Value (2013): 6.14 | Impact Factor (2015): 6.391

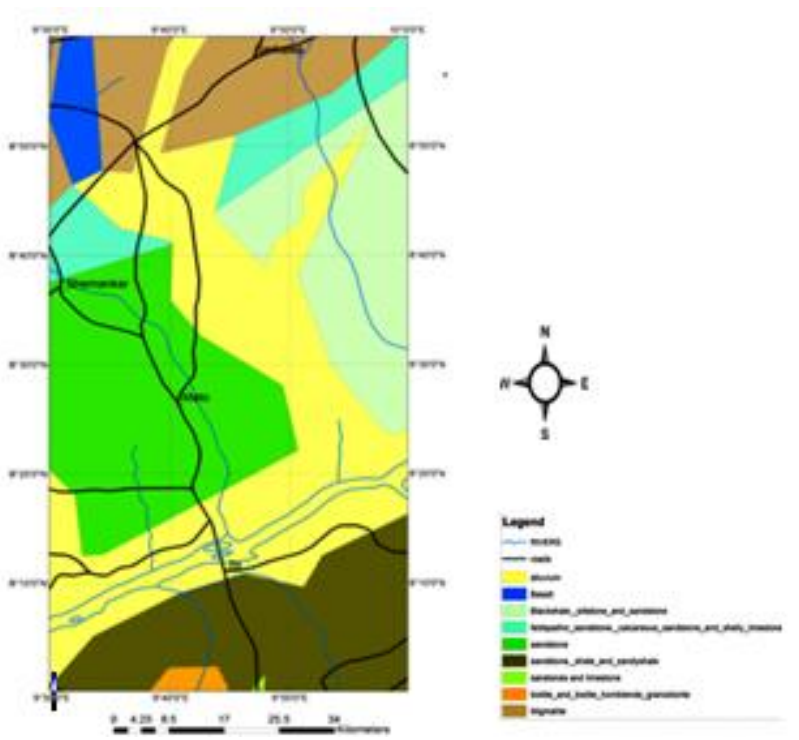

Figure 2: Geologic map of the study area. (Modified from [12]

\section{Materials and Method}

\subsection{Data Acquisition}

The aeromagnetic data used for this work (Fig. 3) was acquired in 2010 by Fugro Airborne survey services for Nigeria Geological Survey Agency. The data was acquired using magnetometers $3 \mathrm{x}$ scintrexCS3 Cesium vapour. The survey was conducted along NW-SE flight lines and tie line along NE-SW direction with $500 \mathrm{~m}$ flight line spacing, Terrain clearance of $80 \mathrm{~m}$ and line spacing of $2 \mathrm{~km}$ were used. The magnetic data recording interval during the survey was 0.1 seconds. All grid data were saved and delivered in Oasis montaj geosoft raster file format. The total intensity magnetic map (Fig.3) as shown below and the residual contour map (Fig. 4) respectively.Spectral analysis of magnetic data were used extensively to derive the depth to certain geological features such as magnetic basement. [23] Stated that the depth factor invariably dominates the shape of the radially averaged power spectrum of the magnetic data. Depth estimation from potential field using power spectra requires a realistic assumption of the statistical properties of the source distributions.

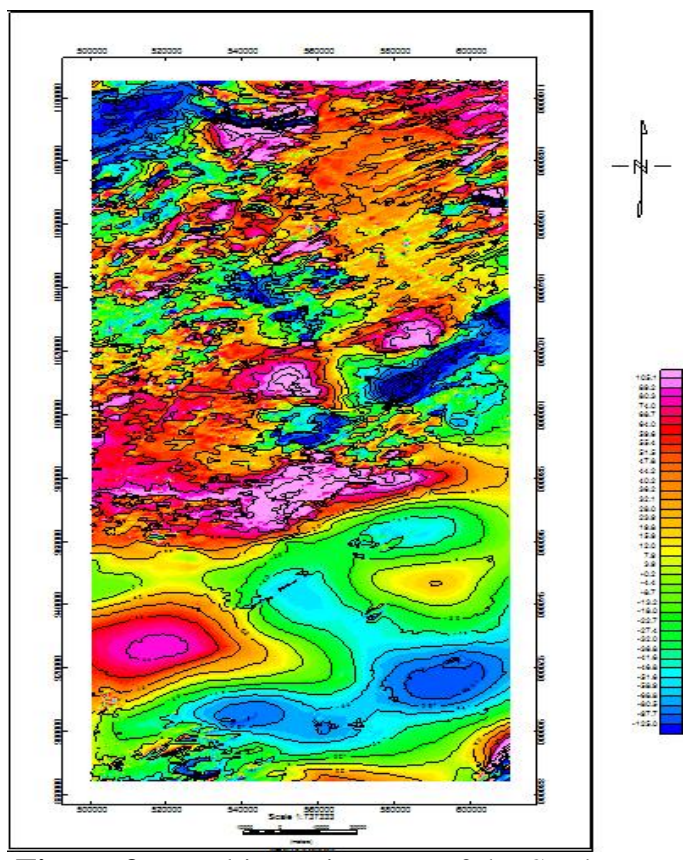

Figure 3: Total intensity map of the Study area

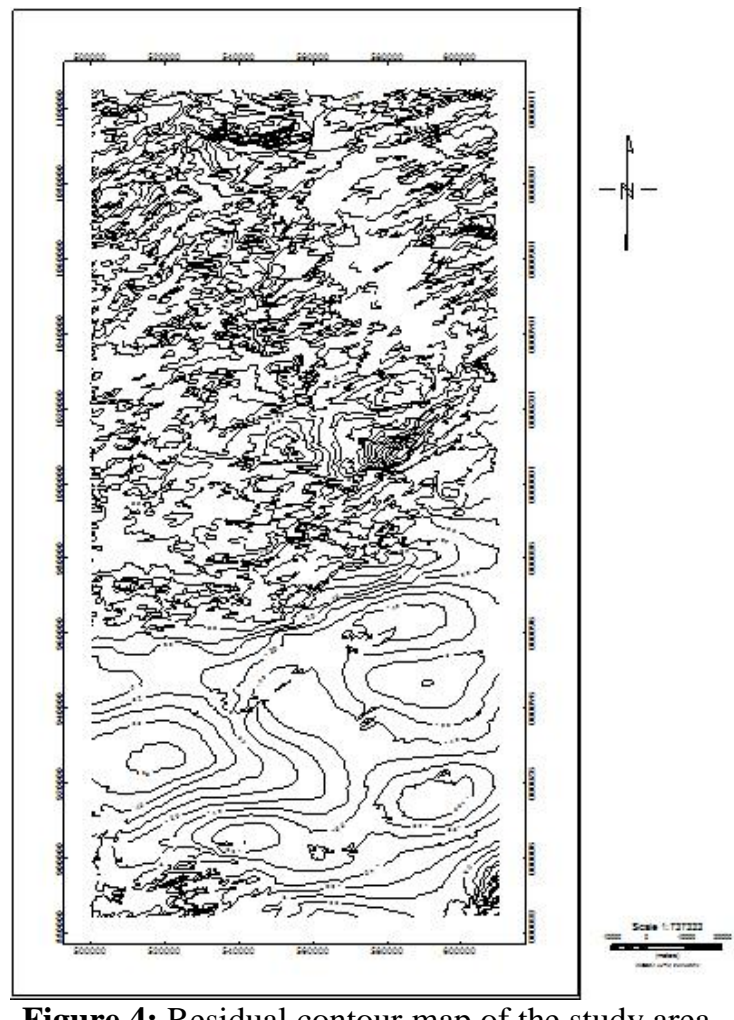

Figure 4: Residual contour map of the study area.

\subsection{Spectral analysis of aeromagnetic data}

\subsubsection{Fourier Transformation}

It has become a familiar concept to interpret aeromagnetic data with one or two dimensional spectral analysis consisting of various frequencies which characterize the anomalies. The amplitude and phase relationship among these frequencies constitute what is known as a "complex line spectrum". The relationship has been used extensively by several authors $[28,8 ; 11 ; 25,18,17,10]$, and [9], interpreted total intensity magnetic map over Garkida and Environs statistically in terms of subsurface structures using two-dimensional power spectral analysis. Recently [9, 10], 


\section{International Journal of Science and Research (IJSR) \\ ISSN (Online): 2319-7064}

Index Copernicus Value (2013): 6.14 | Impact Factor (2015): 6.391

utilized spectral analysis of a simplified mathematical formula for the interpretation of magnetic data over the Mutum Biyu and environs, Jalingo and environs Northeastern Nigeria.

In this research, the Fourier transform technique was applied to the magnetic data. As the authors mentioned earlier pointed out that, if a residual magnetic anomaly map of dimensions $\mathrm{L} \times \mathrm{L}$, is digitized at equal intervals, the values can be expressed in terms of double Fourier series expansion.

$\mathrm{T}(\mathrm{x}, \mathrm{y}) \quad=\sum_{n=0}^{N} \sum_{m=-m}^{M} P_{m}^{n} \cos \left[(2 \pi / \mathrm{L})\left(\mathrm{n}_{\mathrm{x}}+\mathrm{m}-\mathrm{p}\right)\right]+Q_{m}^{n}$

$\operatorname{Sin}\left[(2 \pi / \mathrm{L})\left(\mathrm{n}_{\mathrm{x}}+\mathrm{m}_{\mathrm{y}}\right](1)\right.$

Where $\mathrm{L}=$ length of the square side,

$P_{m}^{n}$ and $Q_{m}^{n}=$ Fourier amplitudes and

$\mathrm{N}, \mathrm{M}=$ number of grid points along the $\mathrm{X}, \mathrm{Y}$ directions.

The sum

$$
P_{m}^{n} \operatorname{Cos}\left[(2 \pi / \mathrm{L})\left(\mathrm{n}_{\mathrm{x}}+\mathrm{m}_{\mathrm{y}}\right)\right]+Q_{m}^{n} \sin \left[(2 \pi / \mathrm{L})\left(\mathrm{n}_{\mathrm{x}}+\mathrm{m}_{\mathrm{y}}\right)\right]
$$

Represents a single partial wave having a particular direction and wavelength for which

$\left(P_{m}^{n}\right)^{2}+\left(Q_{m}^{n}\right)^{2}=\left(C_{m}^{n}\right)^{2} ; C_{m}^{n}$ Is the amplitude of the partial wave, while the frequency of this wave is given

$$
f_{m}^{n}=\left(n^{2}+m^{2}\right)^{1 / 2}
$$

If the logarithms of such an amplitude spectrum are plotted against the frequency, one finds series of points which may be represented by one or more straight lines. The line segment in the higher frequency range is from the shallow sources and the lower harmonics are indicative of sources from deep - seated bodies. The slope of the segment is related to depths [28]

The use of Discrete Fourier transformation involves some practical problems, such as the problems of aliasing, truncation effect or Gibb's phenomenon and the problems associated with the even and odd symmetries of the real and imaginary parts of the Fourier transformation [25].

The aliasing effect arises from the ambiguity in the frequency represented by the sampled data. Frequencies greater than the Nyquist frequency, which tends to impersonate the lower frequencies are known as the aliasing effect. To avoid or reduce the effect of aliasing, frequencies, greater than the Nyquist frequency must be removed through the use of an aliasing filter, which provides high attenuation above the Nyquist frequency. Aliasing can also be reduced through the use of small sampling intervals such that, the Nyguist frequency is equal to or greater than the highest frequency component present in the function being analyzed.

When a limited portion of an aeromagnetic anomaly map or short profile is subjected to Fourier analysis, it is difficult to reconstruct the sharp edges of the anomaly with a limited number of frequencies and this produces what is known as the Gibb's phenomenon. This Gibbs phenomenon or truncation effect is equivalent to the convolution of the Fourier transform of the function with that of a rectangular window which is a sine cardinal function. This convolution introduces ripples at the edges of the function, which manifests itself as spurious oscillations at the discontinuity. Increasing the length of the window makes the Fourier transform tend towards a delta function, with subsequent reduction of the ripples at the edges. The truncation effect can therefore be reduced by selecting a large portion of anomaly or a long profile centered on the feature of interest. An alternative and more effective approach to reducing the truncation effect is by the application of cosine taper to the observed data [17].

\section{Results of the Analysis}

The depths to magnetic sources using spectral analysis of high resolution aeromagnetic data of the area are presented in fig. 5 and table 1 respectively. The results are displayed as shown below, which enabled to give better understanding of the geology of the study area.
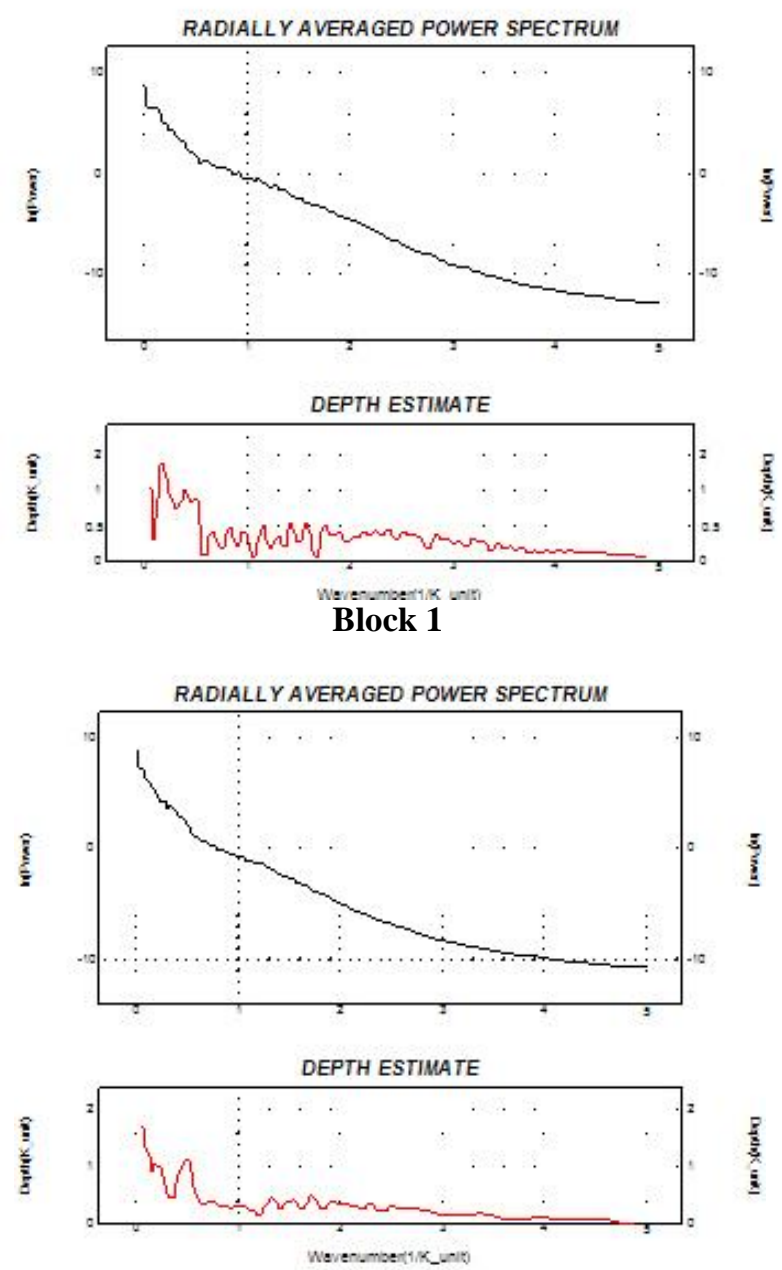

Block 2 


\section{International Journal of Science and Research (IJSR)
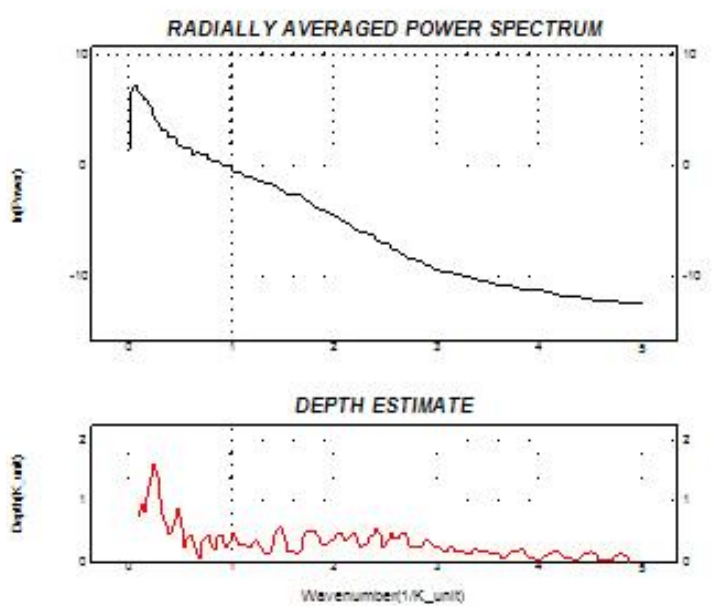

Block 3
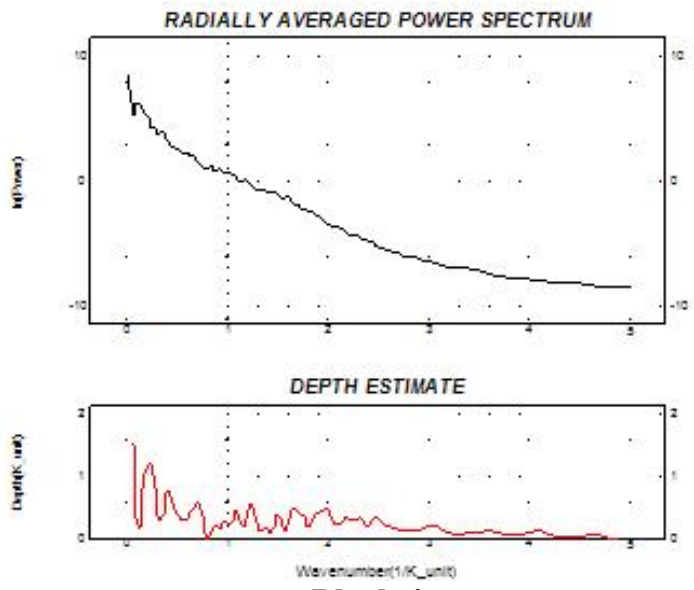

Block 4

Figure 5: Some examples of spectral energy for Blocks 1-4

Table 1: Average depth to magnetic sources from spectral

\begin{tabular}{|c|c|c|c|}
\hline Block 1 & Block 2 & Block 3 & Block 4 \\
D1=3.5 & D1=1.8 & D1=1.85 & D1=1.6 \\
D2=1.0 & D2=1.2 & D2=1.0 & D2=1.3 \\
\hline Block 5 & Block 6 & Block 7 & Block 8 \\
D1=1.7 & D1=2.0 & D1=1.5 & D1=1.2 \\
D2=0.8 & D2=1.2 & D2=0.5 & D2=0.6 \\
\hline Block 9 & Block 10 & Block 11 & Block 12 \\
D1=2.3 & D1=3.0 & D1=1.9 & D1=3.0 \\
D2=0.8 & D2=1.0 & D2=0.8 & D2=1.0 \\
\hline Block 13 & Block 14 & Block 15 & Block 16 \\
D1=1.4 & D1=2.2 & D1=2.0 & D1=2.0 \\
D2=0.8 & & & \\
\hline Block 17 & Block 18 & Block 19 & Block 20 \\
D1=2.0 & D1=2.8 & D1=3.0 & D1=3.00 \\
D2=1.0 & & & D2=2.2 \\
\hline Block 21 & Block 22 & Bock 23 & Block 24 \\
D1=2.5 & D1=3.8 & D1=3.8 & D1=3.7 \\
D2=1.8 & D2=1.8 & & \\
\hline Block 25 & Block 26 & Block 27 & Block 28 \\
D1=4.8 & D1=4.2 & D1=3.8 & D1=4.0 \\
D2=2.8 & D2=1.2 & & \\
\hline Block 29 & Block 30 & Block 31 & Block 32 \\
D1=2.6 & D1=3.0 & D1=4.5 & D1=3.2 \\
\hline
\end{tabular}

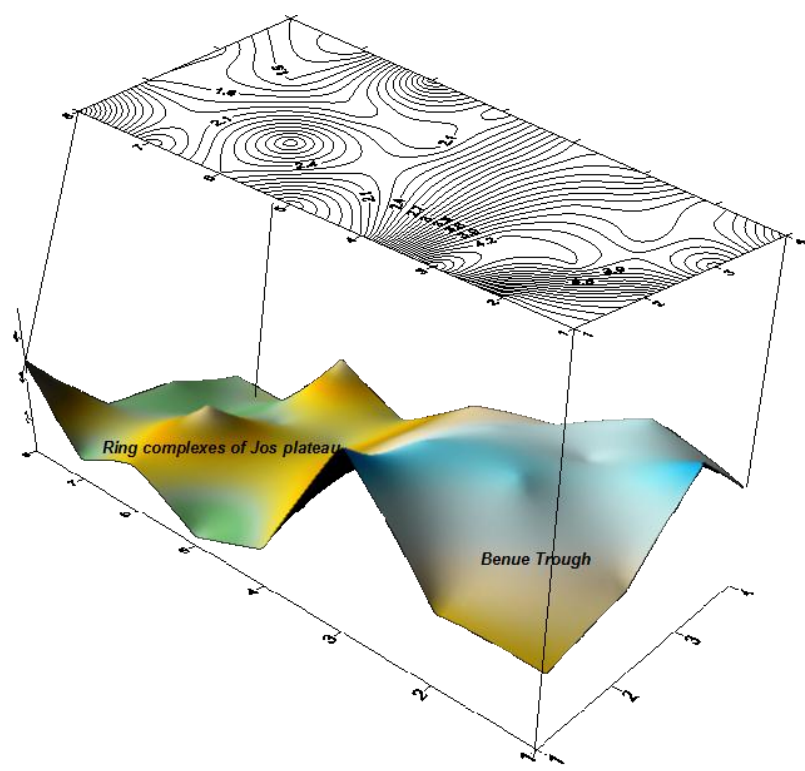

Figure 6: Shows the 2D contour map of D1 superimposed on the 3D D1 spectral energy.

\section{Discussion of Results}

The magnetic source depth determination through spectral analysis suggest $60 \%$ two source depths and $40 \%$ of single source depths under the study area as shown by some typical examples of the spectral blocks in fig.5 and Table 1. The results also suggest the existence of two main source depths under the study area, the deeper and the shallower source. The deeper sources represented by the first segment of the spectra of the blocks reflect the Precambrian basement. The shallow magnetic horizons represented by the second segment of the spectra of the spectral blocks reflect magnetic sources shallower than the basement.

The deeper magnetic sources sediments vary in thickness between 1200 to $4800 \mathrm{~m}$ and the shallower sources vary between 500 to $1000 \mathrm{~m}$. The thick sedimentary cover in the southern part and some areas in the northern part of of the area correspond with the Middle Benue Trough and the thick sediments within the calderas within the Jos Plateau ring complexes (Fig.6). It can also be explained best in terms of intrusive igneous bodies of variable depths existing within the area. The variable basement depths can be closely related to the tectonic and structural evolution of the area.

The thick sedimentary cover in the Middle Benue in the southern part of the study area made it a potential target for detail geophysical exploration for hydrocarbon. The thick sedimentary cover in the northern part is also a potential target for groundwater exploration.

A comparison of the sediments thickness in the study area with those previously estimated from gravity and magnetic analysis shows a good agreement. For example (26) obtained sediment thicknesses that range from 900 to 2200 $\mathrm{m}$ from gravity data interpretation and 900 to $4900 \mathrm{~m}$ from magnetic data interpretation. [24] obtained sediment thicknesses that range between 500 to $4600 \mathrm{~m}$ from magnetic data interpretation over the Upper Benue. [9] the sediment thicknesses from 437 to $2617 \mathrm{~m}$ for deeper sources and $123 \mathrm{~m}$ to $436 \mathrm{~m}$ for shallow sources.

\section{Volume 5 Issue 6, June 2016 www.ijsr.net}




\section{International Journal of Science and Research (IJSR) \\ ISSN (Online): 2319-7064}

Index Copernicus Value (2013): 6.14 | Impact Factor (2015): 6.391

\section{Conclusion}

The results of the present study suggest that the depth to the basement underlying the study area and the thickness of the cretaceous sedimentary cover vary between 1200 to $4800 \mathrm{~m}$ and 500 to $1000 \mathrm{~m}$ respectively. The present work confirmed that the basement topography under the study area is undulating in shape and might had responded to series of volcanic activities that led to the formation of intrusive within the Middle Benue Trough in the southern as well as craters/calderas in the northern parts of the area. Based on these results, the study area can further be investigated for hydrocarbon and mineral exploration.

\section{Acknowledgment}

The authors are Grateful to the geological survey Agency of Nigeria for releasing the aeromagnetic maps. Authors are also grateful to Oasis montaj software which was used for processing the aeromagnetic data.

\section{References}

[1] Alkali, S. C. and Gaiya, S. (2011). Delineation of Linear Structures From Digitized Aeromagnetic Data of The Western Part of The Younger Granite Complex of North Central Nigeria.New York Science Journal, (4)9, pp 56-61

[2] Alkali., S.C. Gaiya., S. and Abba Musa. B.(2012). Depth Estimation of Digitized Aeromagnetic Data of the Western Part of the Younger Granite Rocks of North Central Nigeria, Research Journal of Applied Sciences,Engineeringand Technology,(4)15, pp.24442450.

[3] Avbovbo, A. A., Ayoola, E.O. and Osahon, G.A (1986). Depositional and structural styles in Chad Basin of north-eastern Nigeria. Bulletin American Association Petroleum Geologists, 70, pp 1787-1798.

[4] Braide,S.P. (1992). Geological development, origin and energy mineral resources potential of the Lokoja Formation in the southern Bida Basin. Journ. of Mining and Geology, 28(1), pp 33-44.

[5] Carter, J.D., Barber, W., Tait, E.A. and Jones, G. P. (1963). The geology of parts of Adamawa, Bauchi, and Bornu Provinces in North- Eastern Nigerian. Bulletin of Geology Survey Nigeria, no. 30, p109.

[6] Falconer, J.D. (1911). The geology and geography of Northern Nigeria Macmillan and sons Ltd London

[7] Grant, N.K., Hickman, M.H., Burkholder., F.R. and Powell, J.L. (1972). "Kibaran Metamorphic Belt in PanAfrican Domain of West Africa", . PP 90-91.

[8] Hahn, A. E.,Kind. G, and Mishra, D.C. (1976). Depth estimation of rnagnetic sources by means of Fourier amplitude spectra. Geoph .Prospect. 24, pp. 287 - 309.

[9] Kasidi, S and Nur, A. (2012a). Analysis of aeromagnetic data over Mutum-Biyu an Environs, North-Eastern Nigeria. International research Journal in Engineering and applied sciences, 2, (1), pp.142 - 148.

[10] Kasidi, S. and Nur, A. (2013). Spectral analysis of magnetic data over Jalingo and Environs North-Eastern
Nigeria. International Journal of Science and Research. 2 ( 2), pp. 447- 454. www.ijsr.net

[11] Negi, J.G, Agrawal, P.K, and Rao, K,N. (1983). Three dimensional model of the Koyna area of Maharashtra State (India) based on the spectral analysis of aeromagnetic data. International journal of science and research. 1 (2), pp. 47-53.

[12] Nigeria Geological survey Agency. (2006). Geological map of Nigeria, scale 1: 2,000,000.

[13] Nwogbo, P.O. (1997). Mapping the shallow magnetic sources in the Upper Benue Basin in Nigeria from aerornagnetic. Spectra. 4, pp 325-333.

[14] Nwosu, O.B, and Onuba, L.N. (2013). Spectral reevolution of the magnetic basement depth over part of middle Benue Trough Nigeria using HRAM. 2(5), pp 97-111.

[15] Nur, A. (2001). Spectral analysis and Hilbert transform of gravity data over the south- west of the Chad Basin, Nigeria. Journal of Mining and Geology, 37, pp.155 161.

[16] Nur, A., Onuoha, K. M., and Ofoegbu, C.O. (1994). Spectral analysis of aeromagnetic data over the Middle Benue Trough. Journal of Mining and Geology,30, pp. 211- 217.

[17] Nur. A, Ofoegbu, C.O. and Onuoha K.M. (1999). Estimation of the depth to the curie point Isotherm in the Upper Benue Trough, Nigeria. Jour. Min. Geol. 35 (1), pp. $53-60$.

[18] Nur, A. (2000). Analysis of aeromagnetic data over Yola arm of the Benue Trough, Nigeria. Mining and Geol. 36. pp. 77-84.

[19] Nur A, Kamurena, E and Kasidi S. (2011). Analysis of Aeromagnetic data over Garkida and Environs, NorthEastern Nigeria. Global Journal of Pure and Applied Sciences. 17(2), pp. $209-214$.

[20] Nwogbo, P. O. Ojo, S. B., and Osazuwa, I.B. (1997). Spectral Analysis and Interpretation of Aeromagnetic data over the Upper Benue Trough of Nigeria. Nigeria Journal of Physics, 3 pp 128 - 141.

[21] Offodile, M.E. and Reyment, R.A. (1977). "Stratigraphy of the Keana-Awe area of the Middle Benue Region of Nigeria". Bulletin Geological Institutions University Uppsala (N. S.), 7, pp.37-66.

[22] Ofoegbu, C. O. ( 1984 ) : Aeromagnetic anomalies over the Lower and Middle Benue Trough, Nigeria, Nig, J, Ming and Geol, 21, pp.103 -108.

[23] Ofoegbu, C.O. (1985). Long wave magnetic anomaly and crustal structure underneath the Benue Trough and surrounding regions. Nig. J. Min.and Geol. 22, pp. 45 50.

[24] Ofoegbu, C.O. (1988). An aeromagnetic study of part of the Upper Benue Trough, Nigeria. Jour. Afr. Earth Sci.7, pp. 77 - 90.

[25] Ofoegbu , C.O. and Onuoha, K. M. (1991). Analysis of magnetic data over the Abakaliki Anticlinorium of the lower Benue Trough, Nigeria. Marine and Petr. Geol, 8, pp. $174-183$.

[26] Osazuwa, I.B., Ajakaiye, D. E and Verheijin, P.J.T. (1981). Analysis of the structure of part of the Benue Trough. Journal of science, 2, pp.123-228.

[27] Salako, K. A. (2014). Depth to Basement Determination Using Source Parameter Imaging (SPI) of Aeromagnetic Data: An Application to Upper Benue 


\section{International Journal of Science and Research (IJSR) \\ ISSN (Online): 2319-7064}

Index Copernicus Value (2013): 6.14 | Impact Factor (2015): 6.391

Trough and Borno Basin, Northeast, Nigeria. International Journal of Science and Research, 2(8), pp.48-55.

[28] Spector, A. and Grant, F.S. (1970). Statistical models for interpreting aeromagnetic data, Geophysics, 35, pp. 293 - 302.

[29] Udensi, E.E. and Osazuwa, I.B. (2003). Spectral determination of the depths to the buried magnetic rocks under the Nupe Basin. Nigerian Journal of Physics (NJP), 15 (1). PP. 51 - 59.

[30] United State Geologic Survey, (2013). United State geological Survey geographic information data base

\section{Author Profile}

Dr. Simon Kasidi, received the B.Sc degree in Geology from University of Maiduguri-Nigeria in 2000, M.Sc and Ph.D degree in Applied Geophysics from Modibbo Adama University of Technology, Yola- Nigeria in 2007 and 2013. A lecturer of Geophysics at Adamawa state University, Mubi-Nigeria and Presently on Sabbatical at University of Maiduguri-Nigeria. 